\title{
Surface Modification of Flat Cable Conductors: a Path to Withstand the Aggressive Space Environment
}

\author{
J. Kleiman ${ }^{1} \bullet$ Z. Iskanderova ${ }^{1}$
}

Received: 30 September 2020 / Accepted: 24 November 2020

\begin{abstract}
A novel ion-beam surface treatment process with simultaneous surface renewal (IB/SSR) providing charge-dissipative properties to the treated surfaces was developed at ITL and successfully used for treatment of both sides of variously shaped and sized flat conductor cables (FCC) that are being used in various applications in aerospace, space and commercial programs. The results of surface resistivity (SR) measurements of the front side of FCC's used as interconnects in solar panel arrays on satellites in Geostationary (GEO) orbit averaged around $10 \mathrm{M} \Omega /$ sq for short FCC units and around $8 \mathrm{M} \Omega / s q$ for long units. The SR values for back sides averaged around $18 \mathrm{M} \Omega / \mathrm{sq}$ for both short and long FCCs. These values remained unchanged during $\sim 1$ month storage of the treated FCCs at lab conditions, and after a following 2-2.5 year's storage.

Extended long-term ground-based GEO environment simulation testing experiments (15 years space equivalent) that involved simultaneous exposure to all three GEO environmental factors, i.e. protons, electrons, and UV have been performed on two specially selected FCC sets. These sets included pristine and IB/SSR-treated FCCs, with both front and back FCC surfaces being exposed. It was demonstrated that the surface conductivity obtained on the insulating space polymer films is almost insensitive to space radiation during the 15 years in GEO. It was also shown that the long-term influence of GEO radiation on thermal optical characteristics of both FCCS sides does not significantly differ for pristine and ion-beam treated samples.
\end{abstract}

Keywords: Surface resistivity, charge dissipation, flat cable conductor (FCC), GEO Space environment, ion beam treatment.

\section{Introduction}

Flat conductor cables (FCC) are being used in various applications in aerospace, space and commercial programs. The benefits of using FCC in many interconnecting systems have long been recognized. In a growing number of instances, highly flexible FCC's are more compatible than round wire cables with modern circuit designs, component miniaturization trends, and new packaging techniques.

FCC's are especially important when such criteria as volume and weight reduction need to be taken into consideration, as is the case with space flown hardware. FCC's have a higher packaging density than conventional round wire cables. Use of FCC's in interconnects between the solar cell panels on satellites operating in low Earth orbit

\footnotetext{
$\triangle$ J. Kleiman

jkleiman@itlinc.com

${ }^{1}$ Integrity Testing Laboratory Inc., Markham, Canada
}

(LEO) and geostationary orbits (GEO) is one example of their application in space. However, when used in open space the polymers that the FCC's are made off are being attacked by the environmental factors of space.

In case of the GEO orbits where many satellite operate, the charging of the FCC's by electrons and protons that are present in GEO environment represents a big problem. Also, because the electric orbit-raising (EOR) launches to bring space crafts to GEO are becoming more popular, the spacecraft remains at lower altitudes during the launch/transfer phases. The external surfaces of the spacecraft thus are exposed to atomic oxygen (AO) that is one of the major constituents of the low Earth orbit environment. Due to the significant amount of time (months) spent in the lower orbits, the need arises to protect FCC's and other structures from both the charging in GEO orbits and from the space environmental factors of the low Earth orbit. In case of the low Earth orbit environment the most critical factor is the presence of atomic oxygen that interacts with most of the polymers and erodes them quickly (Fig.1). Even for space bound FCC's that are made of Kapton, a 

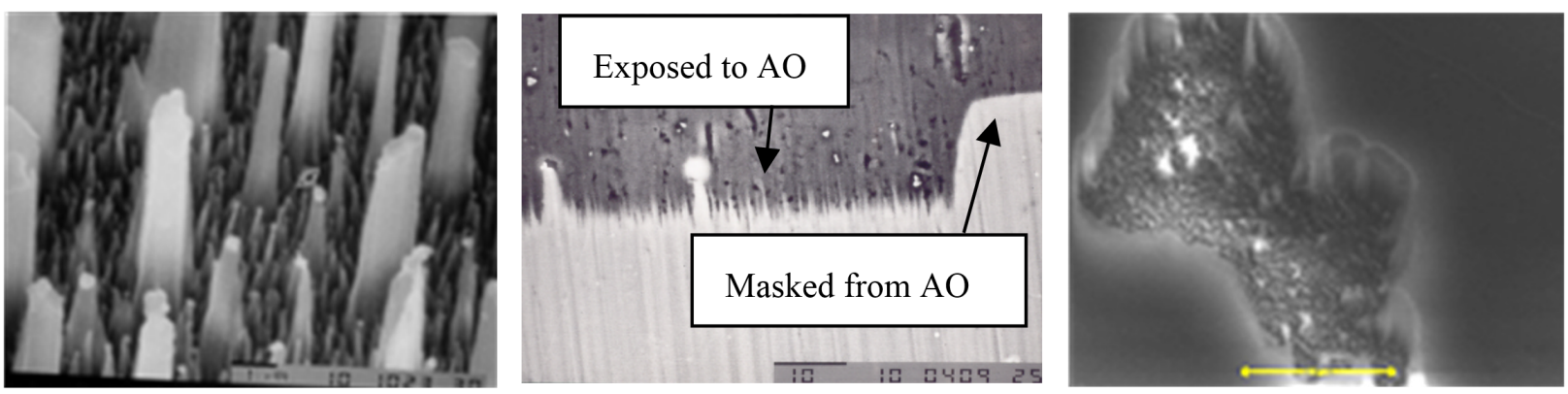

Fig.1. Scanning electron microscopy (SEM) analysis of different polymer materials exposed to accelerated atomic oxygen testing in low Earth orbit space environment simulator. a) Planar secondary electrons SEM image of a PMMA polymer exposed to a fast atomic oxygen (FAO) beam for $6 \mathrm{hrs,} \mathrm{imitating} \sim 2-3$ months in space; $b$ ) Crosssectional backscattered electrons compositional SEM image of a Kapton polymer exposed to a FAO beam for 6 hrs. The area marked as "masked" was protected from the AO beam; c) Planar secondary electrons SEM image of a protective film coated space polymer exposed for $\sim 24$ hours to the FAO beam showing strong erosion of an area that contained, most probably, a defect or a pit through which the erosion started

very stable, high temperature, space-qualified polymer, the atomic oxygen $(\mathrm{AO})$ erosion presents a serious problem that needs to be addressed.

A program was initiated at ITL, using the ion beam treatment process Carbosurf [2 - 4] developed for making space polymer films surfaces charge dissipative, to develop a surface modification treatment to prevent Flexible Cable Connectors (FCC's) used on satellites from space charging effects during long-term modern space missions in GEO. The FCC's are used for solar arrays in GEO orbits and come in different sizes and shapes (Fig. 2a). They are manufactured based on DuPont Pyralux LF1010 that basically consists of a Pyralux LF1010 copper clad laminate and same type coverlay, i.e. Kapton100HN (1 mil) films, joined together by a special acrylic adhesive with thin copper strips pressed in between them at processing stages [1]. As can be seen from Fig. $2 b$ that presents a portion of an FCC, the polymeric surfaces of FCCs are not plain thin films, but have a "grooved" morphology due to the manufacturing techno-logy.
The major objective of the initiated program was to change the surface resistivity of both sides of the FCC's from being completely insulating to having charge dissipative properties, with surface resistivity (SR) in the range of $\sim 10 \mathrm{MOhm} / \mathrm{sq}$ and to maintain these properties in GEO for $\sim 15$ years.

\section{Front and back surfaces of the FCCs units}

Due to differences in technological processes involved in manufacturing of the FCC's, the morphology of the front and back surfaces differed widely. The front shiny side had a featureless, smooth surface, similar to a regular Kapton (Fig. 3a), while the matt back side, when analyzed at higher magnifications, demonstrated a highly developed surface morphology/roughness and significant contamination with small particles (Fig. $3 b$ and $3 c$ ) due to a treatment with water slurry, containing tiny pumice particles, under pressure (to enhance the bonding of copper stripes with an adhesive during FCCs' manufacturing).
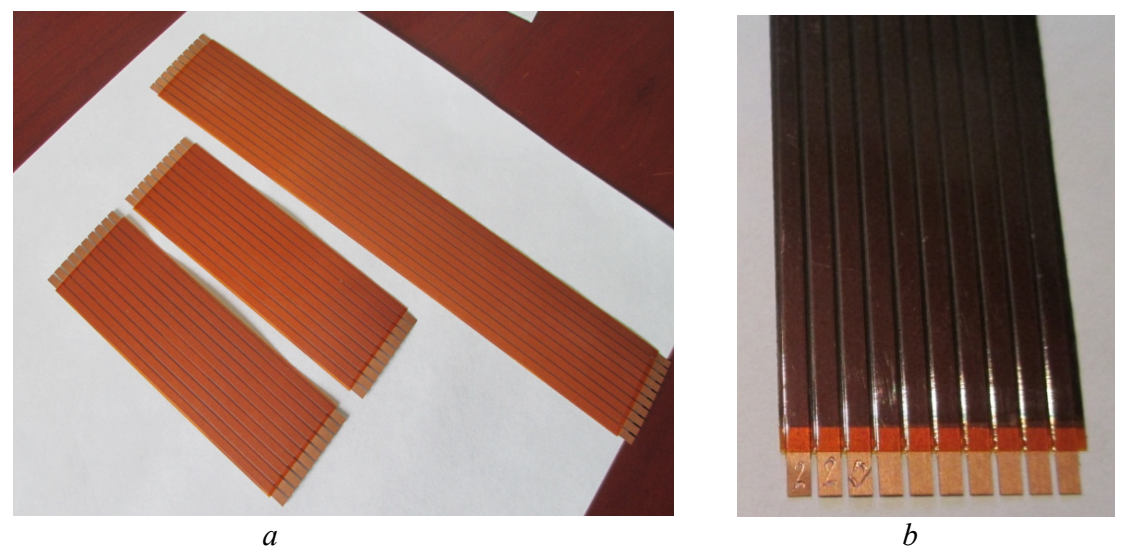

Fig. 2. Optical image of the short and long FCC's used in this program $(a)$ and a portion of the FCC demonstrating the grooved nature of its surface $(b)$. 

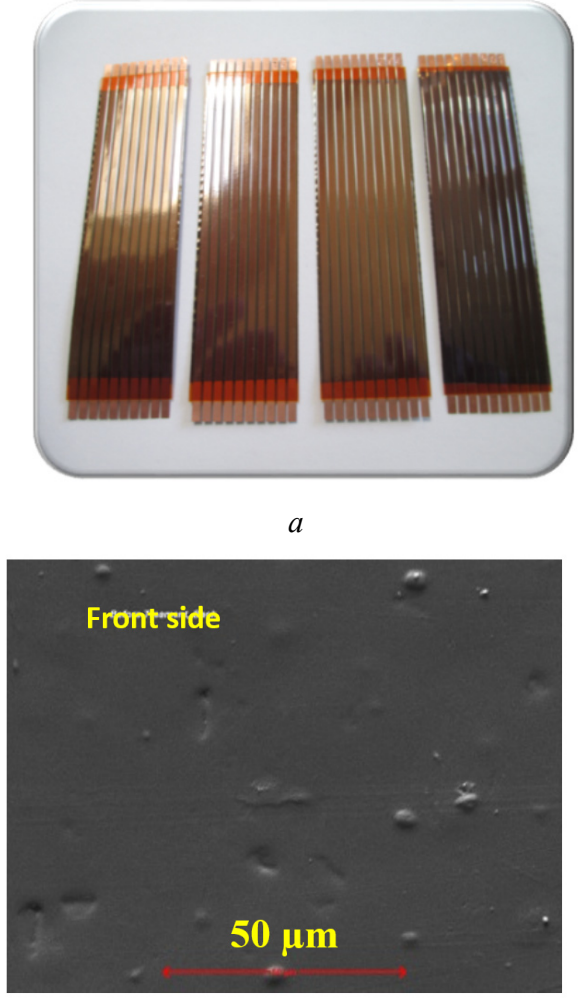

c

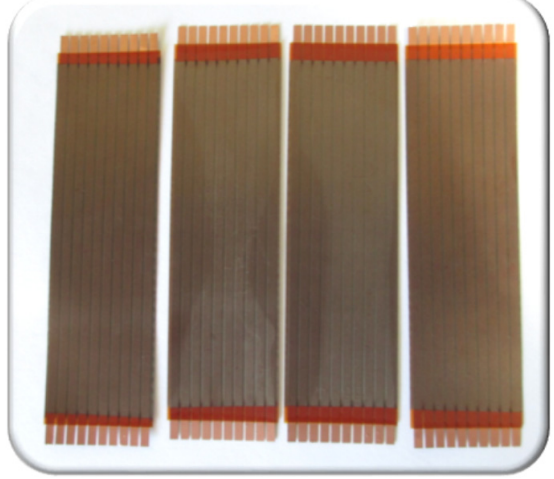

$b$

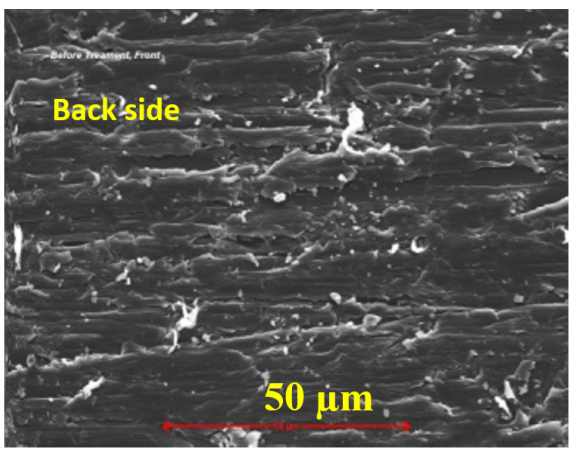

d

Fig. 3. Images of a number of FCCs demonstrating the shiny smooth appearance of the front side $(a)$ and the matt, rough appearance of their back side $(b)$. Surface morphology of the front $(c)$ and back $(d)$ sides is shown in greater details in the scanning electron microscopy images

Special attention had to be paid, therefore, when the ion beam treatment process Carbosurf [2 - 4] was applied to FCCs.

\section{Experimental}

\section{Surface analysis of FCCs}

A number of surface analytical techniques, such as SEM/EDS and XPS were used before and after various surface treatments and GEO imitation testing to evaluate changes in surface morphology and elemental composition. In addition, such functional properties as surface resistivity and thermal optical properties have been also measured using equipment and facilities, described in [2-4].

\section{Ion beam surface treatment of FCCs for charge dissipation}

A special version of a process involving ion bombardment with simultaneous surface renewal was developed and applied in this work for treatment of both the front and the back surfaces of the FCCs units. The technological specifics of the process are based on a general approach, previously developed, studied, and patented [5-7], in combination with the innovative Carbosurf ion-beam treatment of thin space polymer films, described in [2-4]. In all experiments, the edges of FCCs were masked by taping them to the surface of a rotating drum with a KaptonHN adhesive tape that covered the external $\mathrm{Cu}$ contacts. The drum was placed inside a high-vacuum chamber with a liner-type gaseous high-power technological ion beam source (Fig. 4). The ion-beam fluence in the conducted experiments has been estimated at $\mathrm{F} \sim 3 \times 10^{17}$ ions $/ \mathrm{cm}^{2}$.

Since Kapton polyimide normally contains a significant amount of absorbed water vapor, special attention was paid to the outgassing procedure. High vacuum Carbosurf ${ }^{\mathrm{TM}}$ treatment can be easily disrupted by the presence in the vacuum chamber of minor amounts of moisture due to samples dehydration and outgassing of trapped air bubbles. Each ion beam treatment run was conducted following a high vacuum outgassing stage during which the FCCs temperature was kept around $35^{\circ} \mathrm{C}$. A number of technical challenges had to be overcome during the ion beam treatment due to temperature limitation caused by the sensitivity of the adhesive used for FCCs manufacturing and to drastic 
difference in higher sputtering rates of the organics and lower rates of the inorganic pumice inclusions on the back sides.

Despite all the technical difficulties, a special approach was found, that allowed for successful ion beam surface treatment of both front and back sides of FCCs. This treatment, when performed at so called "surface renewal" [5] conditions, consisted of adding a pre-defined amount of carbonaceous gas to the ion beam source, in order to compensate for surface sputtering caused by the ion beam. This approach allowed modifying the surface carbonization conditions for both the front and the back side surfaces, with very successful results and long-term stability at storage, i.e. long-time shelf life.

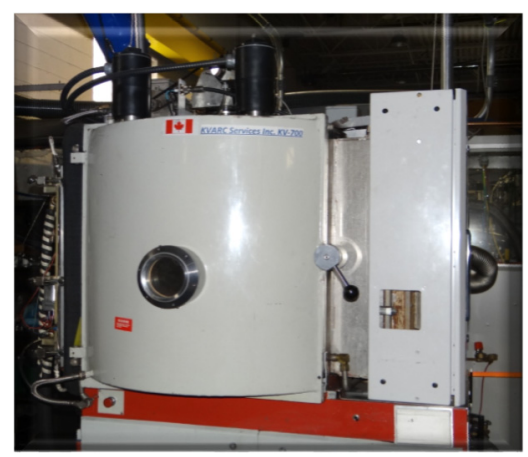

$a$

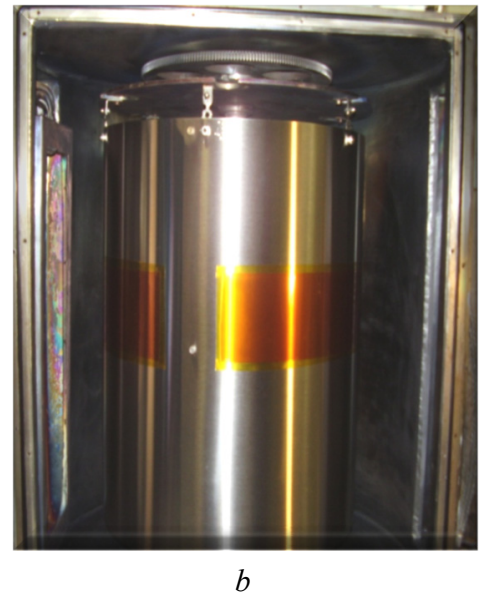

Fig.4. Ion-Beam Treatment and Deposition Facility (a) that is equipped with a high-flux low-energy slit-like ion source and custom-made rotating drum mechanism $(b)$

In the developed technological process, after first run, with the front surface of the FCC's facing the ion beam, the SR was measured using a special SR probe unit following the procedure described in [8] and, if the achieved SR value was acceptable, the same FCCs have been turned over and taped back to the drum with the back side facing the ion beam, and the run was repeated, without influencing the results achieved on the already treated surface. The best treatment conditions have been found as a result of numerous TRIM software calculations and experimental trials [1].

\section{Results and Discussion}

\section{FCC properties after ion beam treatment}

Comparative analysis of surface morphology and elemental composition has been performed on front and back surfaces of a number of FCCs in "as received" condition and after the treatment, as described above, using optical microscopy and SEM/EDS. Comparing the images in Figs. $3 c$ and $3 d$ with the images in Figs. $5 a$ and $5 b$, it can be suggested that the developed ion-beam treatment did not influence the surface morphology of the FCC's. Optical microscopy evaluation confirmed that the front surface remained shiny and smooth and the back surface appeared matt, with both sides becoming darker in appearance.

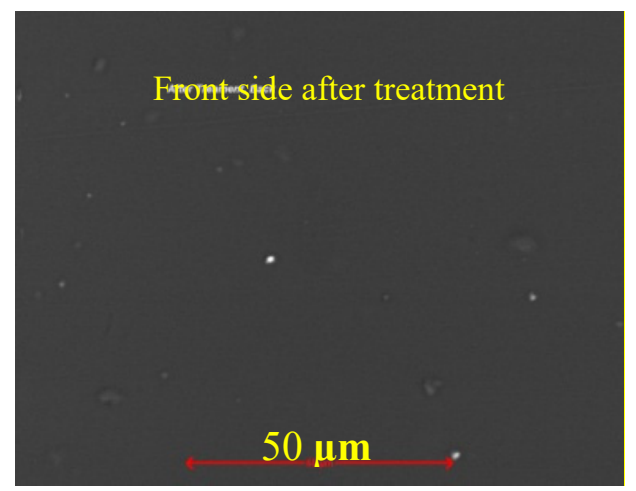

$a$

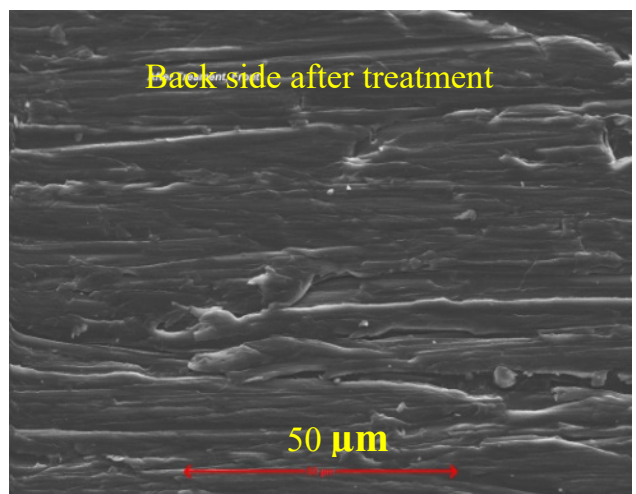

$b$

Fig. 5. Planar scanning electron microscopy analysis of the FCC surfaces after ion-beam treatment. Secondary electrons SEM images of the fronts side surface $(a)$ and the back-side surface (b)

The average SR values for the smooth, front surfaces of all treated long and short FCC have been found to fall between $7.4 \mathrm{M} \Omega / \mathrm{sq}$ and $9.6 \mathrm{M} \Omega / \mathrm{sq}$ that are even lower than the $10 \mathrm{M} \Sigma / \mathrm{sq}$, initially required. The average SR values measured for the rough, back surfaces were between 13.3 $\mathrm{M} \Omega / \mathrm{sq}$ and $21.0 \mathrm{M} \Omega / \mathrm{sq}$, i.e. the average SR values achieved for the back surfaces are approximately twice higher when compared to the corresponding averages of 
the front side. While the differences between the smooth front and rough back surfaces that were due to the contamination of the rough side with pumice particles could not be completely eliminated, it was possible to minimize their influence on the treatment results. This achievement should be considered as an exceptionally good outcome of the developed innovative treatment technology.

The measured SR values demonstrated an exceptional stability that deviated less than $2 \%$ of the initial values following at least 1 month of storage, and later extended up to 2-2.5 years of storage in laboratory conditions. We attribute these minor discrepancies just to the measurement accuracy of the SR values by the used contact method.

The results for reflectance measurements for a pristine FCC sample \#2, labelled 25 for front glossy side and $2 \mathrm{M}$ for back matt side, are presented in Fig. $7 a$. The reflectance spectra and $\alpha$ values for both glossy front (1B) and matt back (1M) surfaces of an ion beam treated sample \#1 are presented in Fig. $7 b$.

Comparing the results presented in Fig. $6 a$ and $6 b$, it is obvious that after the ion-beam treatment the solar reflectance is always less on the darker back side and that the ion-beam treatment significantly decreased the solar reflectance, i.e. increase the solar absorptance, on both front and back sides, influencing the back surface comparatively more than the front one. It is clearly seen that the ion-beam treatment reduced the reflectance in both visible and near infrared spectral regions. The thermal emittance $(\varepsilon)$ results changed insignificantly on both surfaces due to ion-beam treatment.

The developed technology allowed us to convert the electrically insulating FCC surfaces to fully charge dissipative, with surface resistivity properties remaining stable in short and long term laboratory storage conditions.

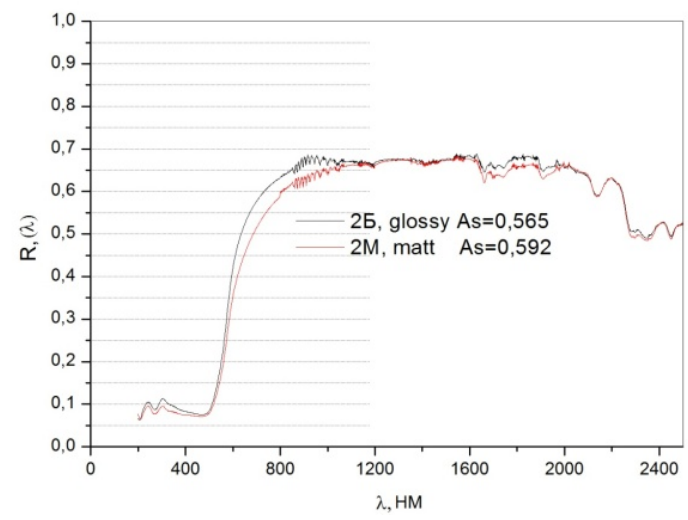

\section{FCC properties after simulated GEO envi- ronment exposures}

Nonmetallic materials used in space systems are affected by electrons and protons in a broad energy interval, electromagnetic solar radiation (both the near and the far ultraviolet radiation), and X-ray radiation. The response of nonmetallic materials to radiation depends on the type of radiation and its energy that defines the ionization losses density, and the radiation response of materials depends on these losses.

A range of GEO-imitating testing procedures have been practically used for a number of years by NASA, European Space Agency and Russian space professionals. However, a significant effort had been made in the last 12 15 years to develop an International Standard that finally resulted in publication of the latest version of "Space systems -- Space environment -- Simulation guidelines for radiation exposure of non-metallic materials" in 2010 [9].

Ion-beam treated and original FCC units had been exposed to GEO-imitating environment using a unique testing facility designed for studying physical-chemical properties of materials and coatings under separate and combined action of space factors that may influence the materials in GEO. Those factors to consider are vacuum as low as $10^{-5} \mathrm{~Pa}$, electrons and protons with energies up to 50 $\mathrm{keV}$, solar electromagnetic radiation up to $10 \mathrm{SEE}$ (solar exposure equivalent) and temperature in the range of $\pm 150^{\circ} \mathrm{C}[3,4,8,10]$.

Depending on the actual expected GEO exposure time, and the selected acceleration factor, the duration of GEO simulation experiment is defined by a computerized system for measurement, control, and monitoring. Functional properties of the tested materials were evaluated before and after the completion of testing using appropriate testing methodologies and instrumentation, in

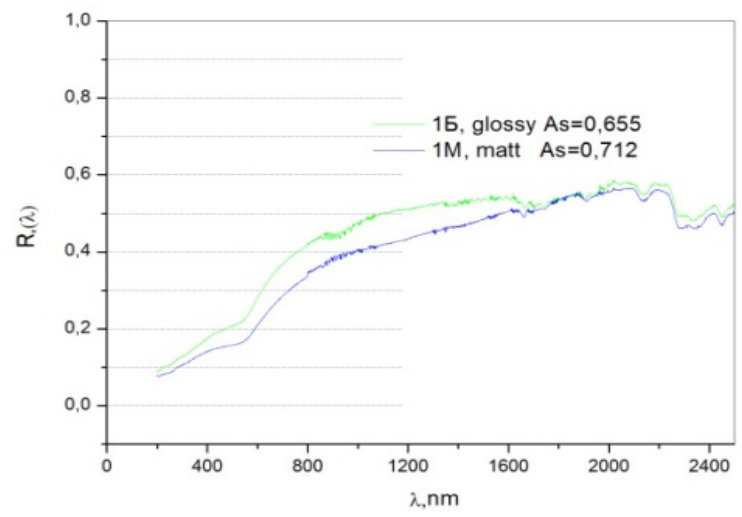

$b$

Fig. 6. Solar reflectance spectra and solar absorptance values for pristine and ion - beam treated FCC's. $a$ ) Data for glossy front (2B) and matt back (2M) sides of the pristine FCC sample \#2; $b$ ) Data for glossy front (1B) and matt back (1M) surfaces of an ion-beam treated FCC (sample \#1) 
order to evaluate the effects of radiation exposure. Thermal-optical properties (such as solar absorptance and thermal emittance) are normally measured, as well as electrophysical characteristics such as surface and volume resistivity, if required.

Every set of FCC units had been placed in a special custom-made sample holder (as shown in Fig. 6) measuring $10 \mathrm{~cm}$ by $10 \mathrm{~cm}$ that was attached to a water cooled base, maintaining the temperature of tested samples mostly around $20^{\circ} \mathrm{C}$. The holders with samples were subjected to combined irradiation consisting of protons, electrons and ultra-violet light. The first set of three FCC units had been subjected to 33 hours of combined $\mathrm{p}^{+}+\mathrm{e}^{-}+\mathrm{UV}$ irradiation, with proton energy $E_{p}=20 \mathrm{keV}$, current density equal to $J_{p}$ $=5 \cdot 10^{11} \mathrm{~s}^{-1} \mathrm{~cm}^{-2}$, electrons energy $\mathrm{E}_{\mathrm{e}}=40 \mathrm{keV}$, current density of $\mathrm{J}_{\mathrm{e}}=5 \cdot 10^{11} \mathrm{~s}^{-1} \mathrm{~cm}^{-2}$ and with simultaneous UV exposure. The selected conditions correspond to a total proton fluence equal to $F_{p}=6 \cdot 10^{16} \mathrm{~cm}^{-2}$ that roughly corresponds to 15 years of equivalent GEO exposure. Due to wellknown limitations, accepted by the space materials community, the UV exposure was selected at 2 times the intensity of solar light. Temperature of the samples was kept around $52^{\circ} \mathrm{C}$ during testing experiments.

Pictures of the tested samples had been acquired and surface resistivity measurements performed after intermediate timing of $\sim 5$ years, and then after final 15 years of space equivalent GEO exposure. Fig. 7 shows the results of the intermediate and the final appearance of the samples. The apparently visible differences (the degree of darkening) demonstrate the increasing effect of simulated GEO radiation on the surfaces of tested FCC units. It is obvious that both sides of pristine and ion-beam treated samples, exposed to GEO-simulating environment, become darker after 5 years, and finally strongly blackened after 15 years. The images in Fig. 7 clearly illustrate the visual differences between the front and back surfaces of tested FCC units the front side of exposed FCCs looked almost black, but remained glossy, while back surface looked dark greyblackish, but remained matt.

\section{Influence of GEO Environment on Thermal Optical Characteristics}

Solar reflectance spectra have been measured for a number of a) pristine, b) treated and c) GEO tested FCCs and solar absorptance values $\alpha$ have been calculated, based on these measurements.

The results of reflectance measurements on a set of samples that underwent the GEO testing are shown in Fig. 8. It was very important to define the final thermal optical properties for both front and back surfaces of pristine and ion-beam treated FCCs after GEO testing (Fig. 8), in order to provide the forecast of their potential end-of-life (EOL) properties after 15 years in GEO space environment. Table I summarizes the data on the thermal optical characteristics of a set of pristine, ion-beam treated and exposed to the GEO factors samples.
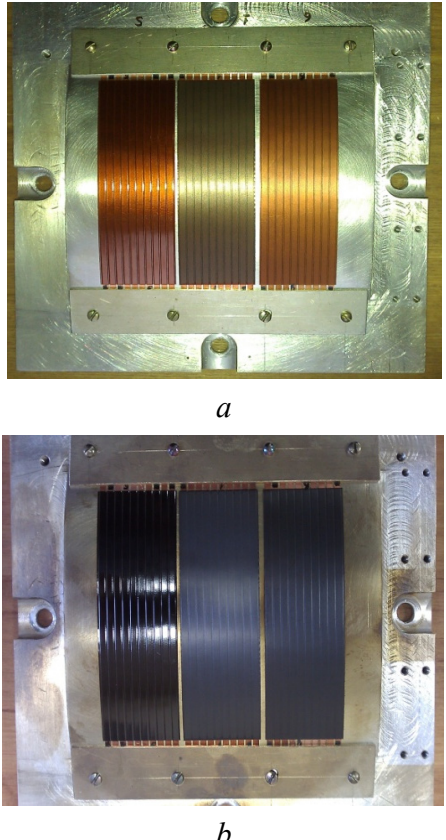

Fig. 7. FCC samples exposed to a GEO environment for $\sim 5(a)$ and $15(b)$ space equivalent years

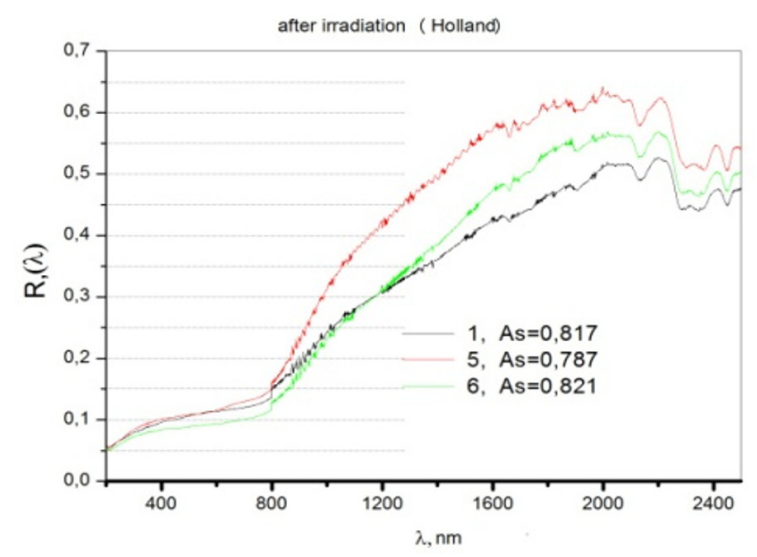

Fig. 8. Solar reflectance spectra and solar absorptance values for GEO-exposed FCC's to an equivalent 15 years in GEO

Table I. Thermal Optical Characteristics of a Pristine, Ion-Beam treated and GEO tested FCC samples

\begin{tabular}{|c|c|c|c|c|}
\hline $\begin{array}{c}\text { Sample } \\
\text { ID }\end{array}$ & Side & $\begin{array}{c}\text { Solar } \\
\text { Absorptance } \alpha\end{array}$ & $\begin{array}{c}\text { Thermal } \\
\text { Emittance } \varepsilon\end{array}$ & $\alpha / \varepsilon$ \\
\hline \multirow{2}{*}{ Pristine } & Front & 0.565 & 0.81 & 0.70 \\
\cline { 2 - 5 } & Back & 0.592 & $0.80-0.81$ & 0.74 \\
\hline $\begin{array}{c}\text { Ion- } \\
\text { Beam } \\
\text { Treated }\end{array}$ & Front & $0.691-0.695$ & $0.79-0.80$ & $\leq 0.88$ \\
\cline { 2 - 5 } & Back & $0.712-0.714$ & 0.80 & $\leq 0.89$ \\
\hline $\begin{array}{c}\text { GEO- } \\
\text { Tested }\end{array}$ & Front & 0.787 & $0.78-0.82$ & 1.01 \\
\cline { 2 - 5 } & Back & $0.817-0.821$ & $0.79-0.81$ & $\leq 1.04$ \\
\hline
\end{tabular}


As can be seen from the data in Table I, the change in solar absorptance due to the ion-beam treatment for front FCC surface is around $\Delta \alpha_{\mathrm{s}}=0.13$ that is further increased to $\Delta \alpha_{\mathrm{s}}=0.22$ after the GEO exposure, and for the back surface it is around $\Delta \alpha_{\mathrm{s}}=0.12$ that is also further increased to $\Delta \alpha_{\mathrm{s}}=0.23$ after the GEO exposure. The thermal emittance measurements did not show any measurable change after ion-beam treatment. Similar trends and even close numerical values have been shown in [2-4] after the ion-beam treatment of Kapton $100 \mathrm{HN}$ thin film.

It is clear, that for ion-beam treated sample the solar reflectance dropped also in both visible and infrared areas and the solar absorptance increased up to almost the same values for front and back surfaces, as for pristine GEO tested FCCs. Thermal emittance changed insignificantly, remaining around $\varepsilon=0.80-0.02$.

A conclusion can be made, that the developed ionbeam treatment does increase the solar absorptance of the treated FCCs surfaces; however, it practically almost does not have an influence on the final thermal optical characteristics of the FCCs after 15 years in GEO space environment. The darkening effects in pristine and ion-beam treated surfaces and the change of the thermal optical characteristics are almost equally strongly pronounced on both sides of pristine and ion-beam treated FCCs.

It is important to note that in the course of this project an extended Program of Space Specification that included a variety of tests, required for certification of the treated Flexible Cable Conductors for Solar Arrays in longterm GEO environment applications was conducted and accomplished.
In all pristine FCCs, exposed to the GEO simulating testing, after both 5 years and 15 years of GEO space equivalent exposures, the SR values of the front and the back surfaces exceeded $10^{5} \mathrm{M} \Omega / \mathrm{sq}$, or $10^{11} \Omega / \mathrm{sq}$, i.e. remained fully insulating. A decrease in measured SR values was found on all ion-beam treated samples after 15 years GEO space equivalent testing. The SR values decreased roughly by two orders at front and back, in comparison to $\mathrm{SR}=10^{15} \Sigma / \mathrm{sq}$ for pristine $\mathrm{FCCs}$, identifying a radiationdriven SR decrease at $\sim$ two orders of magnitude for the full radiation exposure used in this study (Fig. 9).

\section{Conclusions}

An innovative ion-beam treatment process with simultaneous surface renewal (IB/SSR) was developed at ITL and successfully used for treatment of both sides of spacebound FCCs. The results of SR measurements of the FCC's front sides averaged around $10 \mathrm{M} \Omega / \mathrm{sq}$ for short $\mathrm{FCC}$ units and around $8 \mathrm{M} \Omega / \mathrm{sq}$ for long units. The SR values for back sides averaged around $18 \mathrm{M} \Omega / \mathrm{sq}$ for both short and long FCCs. These values remained unchanged during $\sim 1$ month storage of the treated FCCs at lab conditions, and following a 2-2.5 year's storage. Extended long-term ground-based GEO environment simulation testing experiments (15 years space equivalent) that involved simultaneous exposure to all three GEO environmental factors, i.e. protons, electrons, and UV have been performed on two specially selected FCC sets. These sets included pristine and IB/SSR-treated FCCs, and radiation exposure was done for both front and back FCC surfaces. It was demonstrated that

\section{Surface resistivity of three FCC samples vs time of simulated GEO exposure}

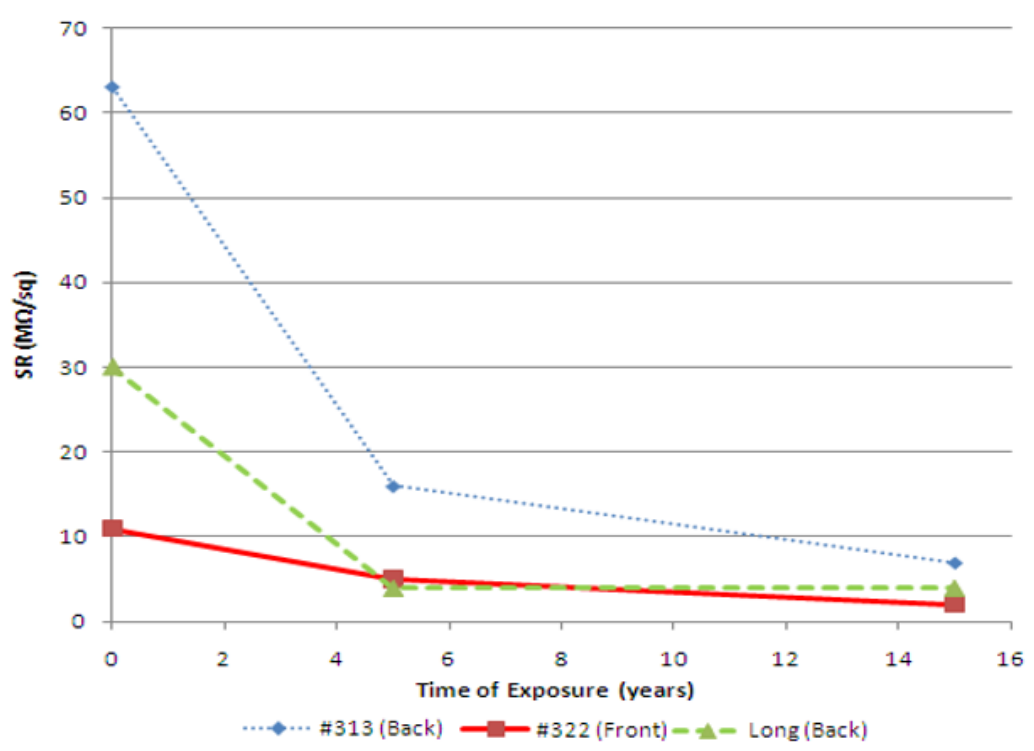

Fig. 9. Surface Resistivity data for three ion-beam treated FCCs vs.GEO exposure equivalent testing time 
the surface conductivity obtained on the insulating space polymer films is almost insensitive to space radiation during the 15 years in GEO. It was also shown that the longterm influence of GEO radiation on thermal optical characteristics of both FCCs sides does not significantly differ for pristine and ion-beam treated samples.
Acknowledgments. We are thankful to ITL staff members for assistance in experimental work and document preparation in course of the Project and for providing surface analysis on FCC samples.

\section{References}

[1] Z. Iskanderova and J. Kleiman, Ion-beam Treatment Technology for Space FCC's to Provide Charge Dissipative Surfaces Resistant to GEO Environment - Final Report to Airbus Defence and Space, Contract G30/4509250924, ITL- 020911-11021, 2011.

[2] J.I. Kleiman, Z. Iskanderova, V. Issoupov and F. Bussieres, "CARBOSURFTM - Surface Modification Technology for Charge Dissipative and RF-transparent GEO Durable Space Polymers", in Protection of Materials and Structures from Space Environment, Proceedings of the 9-th Int. Conference, Canada, pp.588-599, 2008. https://doi.org/10.1063/1.3076874

[3] Z. Iskanderova, J. Kleiman, F. Bussieres, US Patent No. 9, 174,396 B2, Nov 3, 2015

[4] J.I. Kleiman et al., Sodhi Ion-beam Treatment for Enhancement of Durability and Surface Conductivity of Space Polymers: Results, Analysis, Mechanisms, in Protection of Materials and Structures from the Space Environment, Springer, Astrophysics and Space Science Proceedings 32, pp. 317-326, 2013. https://doi.org/10.1007/978-3-642-30229-9_29

[5] U.F. Arifov, Z.A. Iskanderova and T.D. Radzhabov, Method of multilayered structures formation by simultaneous or alternating films deposition and ion bombardment, Patent of USSR, \# 471631, 25.05. 1975 (In Russian). (1975)

[6] Z.A. Iskanderova, T.D. Radjabov, E. O. Arutunova and G.R. Rakhimova, Thin film simultaneous deposition on membrane surface for permeability increase of gas being implanted (theoretical consideration), Vacuum, Vol. 35, Issue 1, pp.5-8, January, 1985. https://doi.org/10.1016/0042-207X(85)90068-5

[7] Z.A. Iskanderova et al., "A Model of a Combined Film Deposition and Ion Bombardment for Coatings Formation”, Proceedings of MRS Fall Meeting, vol. 128, 1988. https://doi.org/10.1557/PROC-128-169

[8] ASTM Standard D257-99, "Standard Test Methods for DC resistance or conductance of insulating materials", V.15.03

[9] International Standard ISO 15856:2010(E): Space systems - space environment - simulation guidelines for radiation exposure of non-metallic materials

[10] I.A. Smirnov, "Radiation-induced conductivity of polymers at long-time radiation exposure", PhD Thesis, Russia (In Russian), 2006.

\section{Процеси поверхневих модифікацій плоских кабельник провідників: шлях, щоб видалити агресивне космічне середовище}

\section{Я. И. Клейман, З. Іскандерова}

Анотація. Новий процес обробки поверхні іонно-променевою поверхнею з одночасним оновленням поверхні (IB / SSR), щчо забезпечує дисипативні властивості заряду оброблених поверхонь, був розроблений в ITL і успішно використаний для обробки обох сторін різної форми та розміру плоских провідних кабелів використовуються для різних застосувань в аерокосмічній, космічній та комерційній програмах. Результати вимірювань поверхневого опору (SR) на лицьовій стороні FCC, щзо використовуються як взаємозв'язки в масивах сонячних панелей на супутниках на геостачіонарній орбіті (GEO), складали в середньому близько 10 MOм / кв. Для коротких блоків FCC та близько 8 MOм / кв. Для довгих блоків. Значення SR для тильних сторін у середньому становили близько 18 МОм / кв. Для коротких і довгих FСС. Ці значення залишались незмінними протягом 1 місячя зберігання оброблених FCC у лабораторних умовах та після наступного 2-2,5 року зберігання.

Розширені довготермінові експерименти з моделювання навколишнього середовища GEO (15-річний космічний еквівалент), які передбачали одночасний вплив усіх трьох факторів середовища GЕО, тобто протонів, електронів та УФ, були проведені на двох спеціально підібраних наборах FCC. Ці набори включали незаймані та оброблені IB / SSR FCC, причому як передня, так $і$ задня поверхня FСС були виставлені. Було продемонстровано, щзо поверхнева провідність, отримана на ізолюючих космічних полімерних плівках, майже не чутлива до космічного випромінювання протягом 15 років у ГЕО. Було також показано, щуо довгостроковий вплив ГЕО-випромінювання на теплооптичні характеристики обох сторін ФКК суттєво не відрізняється для зразків, щзо обробляються первинними та обробленими іонним пучком.

Ключові слова: поверхневий опір, розсіювання заряду, плоский провідник (FCC), середовище GEО Sрасе, обробка іонним пучком. 


\section{Процессы поверхностных модификаций плоских кабельных проводников: путь к выдерживанию агрессивной космической среды}

\section{Я. И. Клейман, З. Искандерова}

Аннотация. Новый прочесс ионно-лучевой обработки поверхности с одновременным обновлением поверхности (IB / SSR), обеспечивающий рассеивающие заряд свойства обрабатываемых поверхностей, был разработан в ITL и успешно использован для обработки обеих сторон плоских проводников разной формы и размеров (FCC), которые используются в различных приложениях в аэрокосмических, космических и коммерческих программах. Результаты измерений удельного поверхностного сопротивления (SR) передней стороны панелей FCC, используемых в качестве межсоединений в массивах солнечных панелей на спутниках на геостационарной (GEO) орбите, составили в среднем около $10 \mathrm{MOм} \mathrm{/} \mathrm{кв.} \mathrm{Для} \mathrm{коротких} \mathrm{блоков} \mathrm{FCC}$ и около 8 MOм / кв. Для длинных блоков. Значения SR для задней стороны в среднем составляют около 18 MOм / кв как для коротких, так и для длинных FCC. Эти значения оставались неизменными в течение 1 месяца хранения обработанных FCС в лабораторных условиях и после следующих 2-2,5 лет хранения.

На двух специально отобранных наборах FСС были проведены расширенные долгосрочные эксперименты по моделированию среды на ГСО (космический эквивалент 15 лет), которые включали одновременное воздействие всех трех факторов окружающей среды ГСО, то есть протонов, электронов и УФ-излучения. Эти наборы включали первичные и обработанные ІВ / SSR FCC, с открытыми как передняя, так и задняя поверхности FCC. Было продемонстрировано, что поверхностная проводимость, полученная на изоляционных космических полимерных пленках, практически нечувствительна к космическому излучению за 15 лет работы в GEO. Также было показано, что долговременное влияние излучения GEO на теплооптические характеристики обеих сторон ГЦК существенно не различается для исходных и обработанных ионным пучком образиов. Ключевые слова: Поверхностное сопротивление, рассеивание заряда, плоский проводник (FCC), среда GEO Space, обработка ионным пучком. 